\title{
Cooperative Societies in the Development Discourse of Ibadan, South-western Nigeria DOI: 10.36108/NJSA/4102/12(0240)
}

\author{
Olayinka Akanle \\ Abidemi Folashade Omotara \\ Dauda A. Busari
}

Department of Sociology

Faculty of the Social Sciences

University of Ibadan

Ibadan, Oyo State

Corresponding author: yakanle@yahoo.com, yk.akanle@mail.ui.edu.ng

\begin{abstract}
Development remains a fundamental challenge confronting Nigeria. Hence, governments at all levels and development partners continue to experiment with different innovative frameworks and approaches. Many of the experimented approaches are however poorly understood leading to ineffective programming. Among the strategies for development are cooperative societies. However, more scholarly works are needed to actually understand the development potentialities of cooperatives, sustainability of cooperative societies as agents of development as well as threats to their existence and effectiveness. Against this backdrop, this article examined issues that may impact development capabilities of cooperative societies in Ibadan.
\end{abstract}

Keywords: cooperative societies, cooperative efficiency, sustainability, development, Ibadan

\section{Introduction}

Nigeria presently faces daunting development challenges. These are evident in pervasive poverty, disease burden, unemployment and lack of basic infrastructure. Cooperative societies are veritable engine of growth and development in developing countries, particularly Africa (Federal Ministry of Agriculture and Rural Development [FMA\&RD] 2006, Gibson (2005), Goetz (2003), Gertler (2001), Henehan (1997), Hansmann (1996), Idowu (1996). Cooperative societies are somewhat compatible with the African social system that is hinged on collectivity (agbajowo and ajumose) and collective, community level and united approach to problem solving.

Thus the Yoruba tradition saying that atete owo kan ko gberu dori (only one hand cannot carry load to the head). It is thus not unbecoming that cooperative societies are becoming popular to the extent that states are building formal institutions and structures around them in forms of self-help, grassroots strategy to empowerment and community development. Different associations, age groups, gender categories and occupational groups now leverage on 
cooperative societies to solve problems especially in societies with poor government performance. Adebayo and Yusuf (2004) examined cooperatives among rural famers in Kwara State, Nigeria, for instance to demonstrate cooperate cooperative efficacy in poverty alleviation. Adebayo and Yusuf (2004) consequently concluded that farmer cooperatives are powerful tools in reducing the growing number of resource poor farmers.

In a similar fashion, Ihenacho et. al. (2012) examined cooperatives as empowerment strategies for poverty reduction among members of Aboh Mbaise Area of Imo State, Nigeria and concluded that cooperatives are positively implicated in empowering members. Likewise, Oparaojiaku, Jamilu and Osigwe (2011) concluded that cooperatives are a vehicle for rural development among the people of Ahiazu Mbaise Area of Imo State Nigeria. The Positive Efficacy (PE) of cooperatives was also found in the Southern and Northern District of the country. According to Birchall (2008), cooperatives play a huge role in alleviating poverty in Southern district [see also Akanle, Omotara and Aduku (2013), Alufohai (2003), Birchall, J. (2003a), Birchall (2003b), Birchall, J. (2004), World Bank (2002) and Idowu (1996)]. Documentation of Cooperative Efficacy (DCE) is however not limited to Nigeria. Gibson (2005), Abell (2004), World Bank (2002), Watt (2000), World Bank (2000), World Bank (1993), Birchall (1994) and Thompson (1994) have all examined cooperatives in Nigeria, Europe and elsewhere and have observed that cooperatives serve positive purposes in empowerment and poverty alleviation ${ }^{1}$.

Cooperative Societies thus play useful roles in impacting the members and local communities in some ways [see Johnson and Johnson (2009), Levi (2005), Johnson (2003), Nweze (2003), Schaffer (1999), Thompson (1994)]. This is usually by giving loans with little or no collateral and maintaining social solidarity among members. Cooperative societies not only serve economic and loan giving purposes but also critical social ones. They maintain both socio-economic and cultural solidarity. Environment, democratic, human and socio-economic values are built and sustained through cooperatives. Cooperatives are built on thrust and confidence mainly. Some dark spots in cooperative operations have however led governments to making important laws and create regulatory frameworks for cooperatives. Cooperatives directly contribute to development across levels to the global point by creating local and wholly grassroots owned solutions with combined global impact. Social and kinship networks represent the main thrust and fabrics of cooperatives.

${ }^{1}$ Dogarawa (2005), Gibson (2005), Nigerian Agricultural Cooperative and Rural Development Bank (NACRD) (2004), Nwanoney (2002), Nwanoney (2002), Ambruster (2001), Gertler (2001), Agbo (2000), Henehan (1997), Hansmann (1996), Ajakaiye (1989), Okafor (1979) 
Cooperative operations are also relatively simple making them deployable even in illiterate and semi-literate societies and contexts [Akanle, Omotara and Aduku (2013), Birchall (2008), World Bank (2002)]. According to International Co-operative Alliance, cooperatives are autonomous associations of persons united voluntarily to meet their common economic, social and cultural needs and aspirations through a jointly owned and democratically controlled enterprise ${ }^{2}$. Cooperative societies may thus be very important instruments for development galvanizing as they resonate and deploy social structural patterns and values in manners that may make development more sustainable in the long run. They do not entirely run on neo-liberal economic model of development but very compatible with indigenous knowledge systems (IKS) and efficacious concepts/principles of ajogbe, ajobi, omoluabi and agbajowo.

According to the International Labour Organization (ILO) Fact Sheet Cooperatives and Rural Employment, based on the positive impact on cooperatives, there has been growth in the number of cooperatives. There are about 800 million members in over 100 countries, with about 1 in 2 people in Finland and Singapore, 1 in 3 people in Canada, New Zealand, Honduras and Norway, 1 in 4 people in the United States of America, Malaysia and Germany been cooperators. By contribution to GDP, Kenya cooperatives have the highest at 45 percent followed by New Zealand at 22 percent and cooperatives are documented to contribute an estimated 100 million jobs worldwide ${ }^{3}$ [see also Birchall (2008), FMA \& RD (2006), Goetz (2003), Birchall (2003), FMARD (2002), Anyanwu, Oyefusi, Oaikhenan and Dimowo (1997), Ijere (1977), and Birchall (1994)]. Although various research has been conducted on cooperatives around the world, there is still more to be done on the development impacts, dynamics and ramifications of cooperatives in SubSaharan Africa. There are particularly few studies on cooperatives in urban contexts in Africa and Nigeria particularly. Most studies on cooperatives are based on agriculture, women empowerment capabilities and in rural contexts. Researches on cooperatives in urban contexts are particularly very few leading to poor data and information with implications for sustainable development.

\section{Theoretical Framework}

This article adopts a combination of Functionalism and Social Capital Theory to explain Cooperative Societies in Ibadan. Functionalism explains society through a comparison with living organisms. It comprehends society as a social system in analogy with a living organism. This is why functionalism is also known as organismic model of society. It draws inspiration from the biological sciences and assumes popularity through the works of Talcott Parson even though variants have since emerged (see Akanle and Olutayo, 2013).

\footnotetext{
${ }^{2}$ Visit www.ica.coop used on 26/09/2014.

${ }^{3}$ The International Labour Organization (ILO) Fact Sheet Cooperatives and Rural Employment
} 
Functionalism falls into the category of macro theories that give grand and large scale explanations of social phenomena [Akanle and Olutayo (2013), Otite and Ogionwo (2006)]. For Functionalism, every society functions as a systems and a living organism. For the society to function optimally all aspects of the society, like living organisms' organs, must function healthily and effectively otherwise the society will disintegrate just as living organism will die if any part/organ is sick without adequate cure.

A malfunctioning society is a sign that at least an organ is socially sick and deficient and this must be socially re-engineered for social restoration to save the society from imminent collapse. Functionalists, in a way, thus stress the significance and importance of structure as well as function. Society functions as a structure and every institution functions to preserve the whole. All institutions, values, norms and agencies existing in society owe their existence to the fact that they still serve useful purposes in maintaining the survival of society. Hence, the traditional social institutions; the family, education, economy, political, and religion, for instance and particularly, work together to form and maintain the structure of the society.

Continuous existence of anyone and everything signals importance and function and deficiency in any will affect the whole. In the order of functionalism, the Nigeria society performs less than expected and this is traceable to the deficiencies in the social institutions. Weak institutional performances account for the underdevelopment of the nation. This has led to the resonance and emergence of cooperative societies which are becoming popular in that they are serving important purposes and filling gaps in meeting the development; empowerment, protection, survival, poverty alleviation and cultural pattern maintenance needs of their contexts. The functionalities of cooperative societies justifies their continuous existence and they perform important stabilizing functions of the Nigerian and global social structures for order in the face of imminent collapse occasioned by traditional institutional failures.

Social Capital Theory explains the importance of social and kinship networks and primordial bonds in determining and giving forms to livelihood outcomes. The creative and socio-economic importance of these networks and bonds lead to their codification as capital because they have even more functionality than mere economic capital yet they are not particularly used as practical and pure medium of exchange. Social capital however drives and given forms even to economic capital. Social capital determines the nature and significance of economic capitals and determines consequences of economic capital actions. Social capital drives efficacious actions across social institutions beyond mere economic rationality to combine even economic rationality with socio-cultural and affective actions for group and society actors. Social capital building and deployment within precarious socio- 
economic environments for livelihood improvements actually led to emergence and increase in cooperative actions and societies.

As already shown above, social capitals exist in traditional African societies and are only codified in cooperatives as rational action deployment in hostile neo-liberal capitalistic socio-economic systems like in Nigeria and traditional yet modernizing Ibadan Metropolis. Members of cooperative societies desire more than mere economic loans or funds to finance businesses. They also seek platforms for establishing and building social capital. This social capital is deployed as soon as needed and is constantly re-assessed. While cooperatives are used as means of improving and increasing livelihood, life chances and empowerment strategies, it is the collective works as social enterprises for inclusive economic gains that are more important within the social capital framework.

\section{Methodology}

Our objective in this paper is to examine processes, problems/threats and development prospects/pathways of cooperatives. We captured our problematic as issues and prognosis as pathways. The orientation of this article is Development. We examined cooperatives within the remit of development studies. Our remit is to look at the issues with the sole purpose of how well cooperatives may be development lifelines of Nigeria and developing nations at large. Though academic and social scientific, we expect this article to contribute to the nascent debate around Cooperatives and Development and Cooperatives for Development. The study was a social scientific investigative one to examine the problems and prospects of cooperative societies in Nigeria choosing Ibadan for its socio-economic and historic specificities.

The primary context of study was urban Ibadan (Metropolitan Ibadan). The reason for choosing Ibadan Urban was to capture an important yet usually neglected area in the literature. Many of the existing studies focus in that they usually research rural contexts based on the conviction that rural people experience poverty and livelihood threats more and consequently tend to operate more within cooperatives. Even though rural people experience poverty and livelihood threats more, economic problems and high aspirations in urban centres may also make urban dwellers push more for cooperative advantages which many existing works do not capture. This article is also important because a lot of existing studies on cooperatives have focused more on women to raise gender stakes, thus making a lot of existing studies gender coloured. This article however studied both male and female subjects to have robust and more inclusive perspective for data and findings enhancement, validity and reliability.

In-depth interview guide was developed to gather qualitative data from members of the selected cooperatives. The interview guide was broken into sections to cover the objectives of study. Data were collected for analysis to lead to prognosis. We targeted certain experienced members of cooperatives to enrich data and offer some uniquely important insights into the issues. 
Purposive sampling (snowballing) was adopted because of the nature of research. Sample frame was not existent so we could not sample probabilistically. Also, we targeted specific individuals purposively who later led us to other members with useful experience and information. Because we needed official and reliable information sometimes not readily available to unofficial/new members, we had to snowball across and within the selected cooperatives so we did not use quantitative/probabilistic sampling approach. Because of the nature of the research that focused scattered cooperatives, qualitative sampling was considered more suitable. Six established cooperative societies were included in the study. These cooperatives have been established for appreciable number of years and they have survived shocks. They also have institutional base and have been well run for many years with verifiable track records which makes them more suitable for this study.

The cooperatives included were: Federal Cooperative College Cooperative Investment and Credit Society (FCCCICS) Eleyele, University of Ibadan Muslim Staff Islamic Cooperative Investment and Credit Society (UIMSICICS), Jaja Clinic Cooperative Society (JCCS), Ifelodun-Orogun Unity Cooperative Investment and Credit Society (IUCICS) Agbowo Ibadan, Kajola Cooperative Investment and Credit Society, and University of Ibadan Teacher's Cooperative Society (UITCS). These cooperatives were also included because they operate within and around higher institutions to test for the endearment factors of the elites and elite neighbourhood since most studies on cooperatives have been within the low class societies citing poverty and disempowerment as reasons for doing cooperatives. We organized twelve indepth interviews and two key informant interviews with members and executive members of the selected cooperative societies.

Ethical considerations of anonymity, confidentiality, beneficence and right of refusal and discontinuation were given and explained to research subjects. All subjects participated voluntarily without coercion. Respect for ethical considerations also informs the nature of confidential data analysis used as names of interviewees were not included in data narratives. Data analysis was through content analysis and presented as narratives and ethnographic summaries.

\section{Data Analysis and Discussion}

This section of the article presents the results and discussion of the research conducted. Socio-demographic backgrounds of the respondents were profiled and results were based on data analysis. Thematic approach of presentation by objectives was adopted for the section for clarity. Data analysis and result were based on examination of cooperative history and policy/legal domains in the context, problems and strategic pathways for effective cooperatives to enhance their development inputs. Content analysis and ethnographic summaries were 
adopted for data originality protection and nuanced context capturing for findings and results validity.

Findings suggest that most co-operators are in the middle age 30-40 and very few at age 50 and above. All interviewees were married. The majority of the interviewees were of Yoruba ethnic background; this is not unexpected because the study was carried out in Ibadan a city dominated by the Yoruba people of south-western Nigeria. Next to the Yoruba were respondents of Igbo origin. The majority of the interviewees were within the salary earning elite population and this will give useful insights into the cooperative world of this hitherto poorly studied category. About 86 per cent of the respondents were civil servants while only 14 per cent were traders.

\section{Cooperative history and policy/legal domains}

Although cooperatives are usually built on social networks as social capital, they have developed to the point that states and governments have created legal and policy frameworks to regulate their activities. The legal and policy frameworks are usually to protect members and the state in general. While the social networks, primordial rules and values are important factors leading to establishment of cooperatives, as cooperatives mature within the social systems, these social forces may not be enough to drive and sustain them. The legal and policy frameworks are particularly important as states, governments and even international communities continue to acknowledge the development capabilities of cooperatives. This is clearly demonstrated by the Central Bank of Nigeria's policy intervention that earmarked N220 billion naira as intervention fund for cooperative societies in the country (Daily Independent, 2014). Windows of financings were also opened to cooperatives through the Bank of Agriculture (BoA) and Bank of Industry (BoI). In 2014, The United Nation Development Programme (UNDP) and the Small and Medium Enterprises Development Agency of Nigeria (SMEDAN) built the capacities and provided economic empowerment programmes for women-owned cooperative societies across the country (Daily Independent, 2014); cooperatives have thus crystalized and continued to crystalize in the country ${ }^{4}$.

Many states in Nigeria now have agencies or Ministries maintaining oversight function on cooperative societies. In Oyo state, cooperative societies register with the state government through the Ministry of Commerce and Cooperative under section 7 (1) of the Cooperative Societies Law cap 27 of the Oyo State of Nigeria Laws of 1978 and it is within this law that cooperatives are regulated (see Akanle, Omotara and Aduku, 2013). Cooperative processes and procedures are formalized in the laws. Even though cooperatives developed informally as social capital to perform important development functions to sustain the society, they transform to formal entities once their operations become appreciable to prevent social problems in already stressed

\footnotetext{
${ }^{4}$ See Daily Independent (2014) at http://dailyindependent.com/2014/09/smedan-undptrain-women-coop-target-cbns-n220b-fund/. Accessed 24/09/2014
} 
socio-economic systems. The views of interviewees were uniform on this objective as already presented above. An interviewee's view below captures the general views of all respondents:

We were established by laws, and we are clearly registered by the director of cooperatives in Oyo state with the Ministry of Commerce and Cooperatives... (IDI/male/Ibadan/a cooperative society's official)

The laws that guide cooperative societies are usually within the purview of Ministry of Commerce and Cooperatives. Cooperation led to the introduction of modern cooperatives in Nigeria dating back to 1935 following the acceptance, by the colonial administration, of Mr. C.F. Strickland's Report on the prospects of cooperatives in Nigeria [Federal Ministry of Agriculture and Rural Development [FMA\&RD] (2006), Gibson (2005), Goetz (2003), Gertler (2001), Henehan (1997), Hansmann (1996)]. According to the Federal Ministry of Agriculture and Rural Development (2002), after 79 years, the cooperatives have been growing to the extent that over 5 million people are now members of cooperatives across the country.

\section{Cooperative Operations, Processes, Meetings and Loans}

It is important to find out some issues around the operational processes, meetings and loans in the societies. Operations are important because it impacts organizational outcomes and must be well managed. Meetings also signal the health of systems. Frequency and depth reflect the degree of cooperation in the societies and indicate the level of collective participation which is the hallmark of cooperatives. A number of people join cooperatives to get loans for different purposes. Based our data for Ibadan, the most common purposes of securing loans from cooperatives are: to start/finance business; to buy vehicles; to pay school fees, and to build houses. Because most of our interviewees were salary earners/civil servants, loans to finance business actually ranked lower behind for vehicle and for building houses. Some cooperatives give products to members during festivals at a fee to be repaid instalmentally; for instance, some give Salah rams, fowls for Christmas and New Year and loans for travels.

Dividends are also given to members as cooperatives invest members' contributions in profit yielding ventures. Time and frequency of meetings vary from one cooperative to another depending on number of members, agenda, and urgency of meetings and structure of the particular cooperative. There is no one-size-fits-all template upon which cooperatives run but trust, participation, functionality, social capital and the legislative environment are constant. The structure and operational processes of cooperatives are relatively simple and based on democratic and collective participation. It is not a very hierarchical system but one that is built on collective trust. Executives are elected and 
campaigns are rigorous most usually based on performance and welfare goals. Simple internal audit is a common practice in the process to prevent corruption.

This is actually one of the main reasons governments create legislative and legal framework to guide cooperatives. The simple process of cooperatives makes it amenable to adaptation and practice by even the illiterates and the semi-illiterates. This is why sometimes cooperatives are also associational. It is common to find cooperatives built around trade associations and pressure groups to protect and encourage welfare of members. Even among the most uneducated people, cooperative societies are organized even though the most educated and the most vibrant ones are usually the executives. The level of education, however, determines the roles executive members play. For instance, the treasurer and secretary are usually among the most educated while the president is usually the most influential and the richest. The background narrative was captured by ethnographic summaries presented below as gathered during interviews with co-operators.

On the operations of cooperatives, a member of Cooperative Society opined:

Let me first mention the requirements. A member that wants to collect loan must have been a member for at least 6 months and our own share capital as I know is N5,000. This share capital is like the minimum amount a member can have in the cooperative account and it is the times two of these share capital plus the savings that the cooperative loan to. For example, the minimum contribution is N5,600 out of this N5,000 is the contribution and N500 is for the investment saving and N100 is for tithe. These savings is always deducted from the source... (IDI/male/Ibadan/35-39years old)

Another interviewee from another Cooperative Society submitted thus:

We operate by our members bringing their money at hand, both the refunding and the savings, which will be enter into their pass book, and the pass book will be given back to them I mean the personal one, meanwhile the society will take the official one, and normally the loan to be given according to the constitution should be $x 2$ of the asset, but at times we have some members that are credit worthy, that we do the privilege of getting more than $x 2$ of what they have has asset......(IDI/male/Ibadan/4044years old)

On Meetings, another cooperator observed:

We do meet. Concerning the executives, we meet when there is need for it but for the members, it is always once in a year and the meeting is called annual general meeting....... (IDI/male/ Ibadan/40-44years old) 
On interest on loans given to member an interviewee from another Cooperative society observed:

There is interest on loan, $2 \%$ on reduction balance and this loan also helps in boosting the society's account, but notwithstanding is still not enough .......(IDI/female/Ibadan/45-49 years old)

Another respondent of a religious cooperative gave a different view on loans to cooperators:

We don't take interest on loan given to members, that is why I say we follow the Islamic doctrine in other words, Islamic rules guides us.....(IDI/male/Ibadan Muslim staff Islamic CICS limited/35-39years old)

As shown above, religious dynamics was observed during interviews; cooperatives established on Islamic principles do not charge interest on loan and only ensure repayment of the loan unlike other non-religious cooperatives. It can be observed from the foregoing that cooperatives are simple in processes yet detailed in documentation and usually have structures in place to prevent loans given from becoming bad loans. Hence, meetings are organized on purpose and frequency varies. While some meet once a year at the Annual General Meeting (AGM) others meet monthly but there are always provisions for emergency meetings to deliberate on urgent issues but this is usually by the executives only to be shared later at the general meeting.

\section{Problems and Threats confronting Cooperative Societies}

Whether cooperatives will be sustainable and contribute to development is dependent upon the ramifications of the problems and threats of the societies. It is against this background that this section investigated the problems and threats of cooperative societies. From our data analysis, the major problems cooperatives confront are: insufficient funds, corruption and incompetent/poorly educated leadership. These three major problems are very critical to the efficiency and effectiveness of cooperative societies and must thus be well understood and addressed. Insufficient funds limit the available funds for cooperators and, therefore, limit the overall impact of the societies. Corruption creates waste in the cooperative systems and reduces efficiency. Poor leadership capacity due to incompetence and low education also negate cooperative effectiveness. These problems were identified by interviewees.

An interviewee from a cooperative limited submitted thus:

The major constrain we have is that the needs of our people most often are not met at the end of the month. That is, at times, we will have people requesting 3 million naira and we don't have such amount in account. In other words, most often the needs of our members are more than what we have. We discover that 
members request for the month is always more than what the society has or cannot be sufficient for their demand. In that case, we have the situation whereby some people will apply and might not be able to get the loan as at that month. That is, instead of giving the loan in January it will be postponed. (KII /male/4549years)

Another respondent from another cooperative observed:

The only challenge we have is the issue of money. In this society the money we have is insufficient....... (IDI/male/40-494ears)

Another interviewee concluded:

The reason why many co-operators complain is, sorry to say, the majority of our cooperatives in Nigeria now have bad leaders. You see when a system is good you look at the leaders and vice versa. So majority of the cooperative societies' leaders have not been doing well and that is because of their corruption. Take for instance, a member that has been saving and has plans for the money that, O.K. I will use this money to pay my rent and such member is not given. He will definitely complain because the landlord will not allow him to rest. Where he is expecting fund to come from fund is not coming due to bad leadership. (IDI /male)

These major threats and problems are some of the main reasons some people still operate outside cooperatives. There is a lot of skepticism among many non-cooperative members about the reliability of cooperatives. Many have heard and seen cases of corruption, leadership gaps and mismanagement. Many are also of the view that the capital base of cooperatives is too lean to have appreciable investment implications for them. Many also find it difficult to differentiate cooperatives from ajo (contributions). Many elites and the upper class also perceive cooperatives as low class entities with capacities to cater for only minor needs. People in the middle class are however attracted to cooperatives, but more inclusive participation even among the low and middle class is dependent upon how well these problems and threats are resolved.

\section{Development Potentials and Pathways of Cooperatives}

Our analysis revealed that cooperative societies have the capacity to reduce poverty and drive development in the country and developing nations. This is more so among the low class and the middle class. Across our interview sessions, interviewees demonstrated the conviction that cooperatives are potential engines of growth and development based on their ideological base, low interest rates, dividends, processes, simplicity, the sense of doing together and participatory development framework being adopted. Most of our respondents opined that cooperatives can drive poverty reduction and lead to development. The poverty alleviation, employment generation, small scale 
investment contribution and low interest loans of cooperative societies can actually drive growth and development just as they are capable to reduce poverty. This was captured by our discussants as presented below in the ethnographic summaries:

A male respondent from a Cooperative Society said:

If not for cooperative society here in this organization the story would have been gory. Thank God it is so good that so many of us as teachers own our houses, our cars, a lot of so many wonderful things that other people that are working with this monthly (eh eh) multinational companies are gaining it is through cooperative that we are having them. Cooperatives are the only organizations that I see that you can have what I call compulsory savings unlike bank savings that you can cash out your money anytime you want either through ATM or something else. But here in cooperative, firstly, you cannot get it that day you save it. Secondly, if you are getting it at the end of the month, it is going to be loan. So it is really alleviating a lot of things....... (KII/male/federal cooperative)

Another respondent from another cooperative society submitted thus; Apart from the fact that the members are benefitting from it, those that are not members are also gaining from the society. For instance now every year the society gives nothing less than \#500,000 to the less privileged ones. So by doing this I think cooperative is eradicating poverty to some extent..... (IDI/male/50 years and above)

A major pathway for cooperative society's contribution to development is to allow them operate within the original template of their existence. Members should also play the role of internal performers by been more involved and attend meetings to raise observation. There is also the need for states and governments as well as international development partners to build capacities of cooperative societies' leaders. As at now, more priority is given to women's cooperative societies but men's should not be left out as the two genders are in need of capacity building and empowerment especially relative to management of cooperatives. Internal democratic structures and accounting of the cooperatives must also be strengthened. Cooperatives should not be seen as only low class phenomenon but that which cuts across classes especially at the level of lower and middle classes. 


\section{Conclusion}

What we have done in this article was to examine issues that surround cooperative efficiency. The article was written within the development framework. It is to contribute to development of the context and the country with implications for developing nations generally. As Nigeria faces development challenges, we examined cooperatives as possible engine of growth and development in Nigeria. The focus on cooperatives was because of gaps we found in the literature, practice and development constructions and intervention in Nigeria and developing nations. This article was written for both academic, policy, pragmatic and practice purpose. We have developed the concept of Cooperative Efficiency in our article because we found this concept encapsulates the issues and pathways examined in this article in terms of course of actions and implications of actions and/or inactions.

Against this background, it is possible to conclude that cooperative societies are filling a huge gap in poverty alleviation, employment creation, facilities' provision, socio-cultural bonding, social capital development and sustenance and development driving in the context and the country at large. The gaps, threats and problems identified in this article must however be filled. Enabling laws must be strengthened, members must attend meetings, they must make contributions at meetings and repay loans, democratic space and process of cooperatives must be widened, capacities of leaders must be built in accounting and administrative process, gender issues in cooperative management must be managed and class dynamics must be well factored in because cooperatives cut across classes, gender and spaces.

Issues of cooperative corruption must be addressed by strengthening state oversight, internal audit systems and instituting transparent leadership. Governments and states must however not politically and sentimentally meddle in the affairs of cooperatives so they can retain their original and socially compatible elements that are their cutting edges and trademarks. The social capital and inherent elements functionality must be allowed to subsist against all odds. This is only when Cooperative Efficiency can be instituted as cooperatives remain very promising components of Nigerian development potentialities.

\section{References}

Abell, P. 2004. Cooperative Movement. Encyclopaedia Encarta: 2004 Edition.

Adedayo, A. and Yusuf, O.R. 2004. Rural Poverty Alleviation through Agricultural Cooperatives: A Service Provision Approach in Kwara State. Geo-Studies. 2(1): 1-8.

Agbo, F.U. 2000. Increasing the Output of Cassava through Women Cooperatives. Nigerian Journal of Cooperative Studies. 2(1): 24-38.

Akanle, O. and Olutayo, A.O. 2013. Macro-Sociological Theories. In Olutayo, A.O. and Akanle, O. (eds.). Sociological Theory for African Students. Ibadan: Ibadan University Press. 25-70. 
Alufohai, G.O. and Opia, O.P.B. 2003. Agricultural Cooperatives in Delta State: Private Sector Efforts. Nigeria Journal of Cooperative Studies. 2(2): 105-113.

Ambruster, P. 2001. Cooperative Banks in Europe: Values and Practices to Promote Development. IRU Courier. (3): 10-13.

Anyanwu, J.C.; Oyefusi, A.; Oaikhenan, H. and Dimowo, F.A. 1997. The Structure of The Nigerian Economy (1960-1997. Onitsha: Joanee Educational Publishers.

Birchall, J. 1994. Cooperatives: The Peoples' Business. Manchester: Manchester University Press.

Birchall, J. 2003a. Re-discovering the Cooperative Advantage: Poverty Reduction through Self-help. Geneva: International Labour Organization.

Birchall, J. 2003b. Rediscovering the Cooperative Advantage: Poverty reduction through self-help. ILO. Tenant takes over abandoned housing in New York. 20-25.

Birchall, J. 2004. Co-operatives and the Millennium Development Goals. ILO. Case Studies.

Birchall, J. 2008. The Role and potential of cooperatives in Poverty Reduction. ICA Research Conference, Trento, October, for findings from a survey of cooperatives in Tanzania and Sri Lanka.

Dogarawa, B.A. 2005. The Role of Cooperative Societies in Economic Development, MPRA Paper No. 23161. Available at www.mpra.ub.unimuechem.da/23161. (Accessed on 17/05/2013).

Fapojuwo, O.E., Alarima, C.I. and Abiona, B.G. 2012. Contribution of Cooperative Organizations to Poverty Alleviation in Yewa North Local Government Area of Ogun State, Nigeria. J. Hum Ecol. 40(2): 189-196.

Federal Ministry of Agriculture and Rural Development, 2002. Cooperative Development Policy for Nigeria, Abuja: Federal Government of Nigeria.

Federal Ministry of Agriculture and Rural Development, 2006: Cooperative Development Policy for Nigeria, Abuja: Federal Government of Nigeria.

Gertler, M. 2001. Rural Cooperatives and Sustainable Development. Saskatoon: Centre for the Study of Cooperatives.

Gibson, R. 2005. The Role of Cooperatives in Community Economic Development. RDI Working Paper No. 2005-3.

Goetz, E.G. 2003. Clearing the Way: De-concentrating the Poor. Washington: Urban Institute Press.

Hansmann, H. 1996. The Ownership of Enterprise. Cambridge: Harvard University Press.

Henehan, B, 1997. Cooperating for Sustainability. New York: Cornell University Press.

Idowu, L.A. 1996. Breaking Rural Poverty Gap and Achieving Sustainable Development through Cooperation Activities in Nigeria. In Adedoyin, S.F. and Aihonsu, J.O. (eds.). Sustainable Development in Rural Nigeria. 
Proceedings of the $8^{\text {th }}$ Annual Conference of the Nigeria Rural Sociological Association.

Ihenacho, R.A. Chikaire, J, Ejiogu-Okereke, N. Oguegbuchulam, M.N. Osuagwu, C.O. and Obi, K.U. 2012. Empowerment Strategies of Cooperative Societies for Poverty Reduction among Members in Aboh Mbaise Area of Imo State, Nigeria. Global Advance Research Journal of Agricultural Science. 1(8): 233-239.

Ijere, M.O. 1977. Modernising Nigerian Cooperatives. Lagos: Fred Atoki Publishing Company.

International Labour Organization, 2007. Fact Sheet Cooperatives and Rural Employment.

Johnson, D.W. 2003. Social interdependence: The Interrelationships among Theory, Research, and Practice. American Psychologist. 58(11): 931-945.

Johnson, D.W. and Johnson, F. 2009. Joining Together: Group Theory and Group Skills, $10^{\text {th }}$ Edition. Boston: Allyn and Bacon.

Levi, Y. 2005. How Non-profit and Economy can Co-exist: A Cooperative Perspective. Ireland: International Cooperative Research Institute.

Nigerian Agricultural Cooperative and Rural Development Bank, 2004. Annual Report. Kaduna: NACRDB Press.

Nwanoney, N.P. 2002. The Role of Cooperatives in Development. Enugu: Dumze Press.

Nweze, N.J. 2003. Cooperative Promotion in Rural Areas: A Project Approach. Nigeria Journal of Cooperatives. 2(2): 76-89.

Okafor, F.O. 1979. Socioeconomic criteria for evaluating cooperative efficiency in Nigeria. Review of International Cooperation. 72(4): 8-14.

Oparaojiaku, J., Jamilu, A.A. and Osigwe, T. 2011. Cooperatives: A Vehicle for Rural Development: The Case of Ohiazu Mbaise Area of Imo State, Nigeria. Nature and Science. 9(11): 6-11.

Otite, O. and Ogionwo, W. 2006. An Introduction to Sociological Studies. 2nd edition. Ibadan: Heinemann Educational Books.

Ritzer, G. 2008. Sociological Theory. 7th edition. McGraw-Hill.

Shaffer, J. 1999. Historical Dictionary of the Cooperative Movement. London: Scarecrow Press.

Simmons, R. and Birchall, J. 2008. The Role of Cooperatives in Poverty, South District. Ife PsychologIa. 10(1): 72-84.

Thompson, D. 1994: Cooperative Principles: Then and Now. Minneapolis: National Cooperative Grocers Association.

Watt, P. 2000. Social Investment and Economic Growth: A Strategy to Eradicate Poverty. U.K.: Oxfam.

World Bank. 2002. Poverty in Nigeria: Past, Present and Future. Washington D.C.: World Bank.

World Bank. 1993. Trend in Developing Countries. Washington, DC: The World Bank.

World Bank. 2000. Rural Development: Putting the Pieces Together. Washington, DC: The World Bank. 